\title{
Russian lambic Tetrameter: \\ The Evolution of Its Rhythmic Structure
}

\section{Sergei Liapin*}

\begin{abstract}
To characterize the rhythm of stresses in a line of Russian iambic tetrameter, a frequency profile is often used, i. e., a diagram of the occurrence of real stresses on all feet (ictuses) of the verse line. This article discusses in detail one of the mechanisms that enables the speech factor to influence the formation of the stress profile. It is shown that in Russian iambic tetrameter of the nineteenth and twentieth centuries, the high frequency of stresses of the second ictus is explained by the fact that the beginning of the line more often than not coincides with the beginning of a sentence or clause, and the Russian syntagma is more frequently stressed in the middle. And vice versa, wherever the frequency of enjambments increases, the second ictus is less frequently stressed, because the beginning of the syntagma moves to the middle of the line. Considering the above, the author attempts to characterize the peculiarity of the rhythmic structure of Russian iambic tetrameter in synchronic and diachronic aspects and reveal some major large-scale trends such as the growth of the rhythmic diversity of poetic texts.
\end{abstract}

Keywords: Russian iambic tetrameter, meter, rhythm, evolution, speech structure, speech-based model of verse, enjambment

In memory of James Bailey

In order to study the rhythm of stresses in verse (and the rhythm of Russian iambic tetrameter in particular), we must first distinguish between versification tendencies proper (expressive rhythm) and the external causes that affect the accentual pattern of the line. The strongest external factor is the speech factor. We aim to assess the significance of its influence on the formation of the accentual pattern of verse.

Author's address: Sergei Liapin, Pulkovskaia str. 19-50, St. Petersburg 196158, Russia, email: liapin@mail.ru. 
1.

Let us begin with an example. In 1975, James Bailey analyzed the iambic tetrameter of Konstantin Sluchevsky. Here is Bailey's main conclusion:

The stressing of Slučevskij's narrative verse is exceptional for the middle of the nineteenth century because the second ictus has been weakened to $88.2 \%$ so that there is a near leveling of the first two ictuses (Bailey 1975: 95). ${ }^{1}$

Contrary to Bailey's assertion, his discovery is no exception. One need only compare our data relating to Russian lyroepic verse of the middle and late nineteenth century with the data provided by Bailey (1975) and Taranovsky (1953) - see Table 1.

Table 1. Stress profile of 19th-century Russian iambic tetrameter

\begin{tabular}{|c|c|c|c|c|c|}
\hline & \multicolumn{4}{|c|}{ Ictuses } & \\
\hline & 1 & 2 & 3 & 4 & Total lines \\
\hline 19th-century lyroepic verse ${ }^{2}$ & $81.6 \%$ & $84.3 \%$ & $49.9 \%$ & $100 \%$ & 3,450 \\
\hline Sluchevsky's narrative poems & $84.7 \%$ & $88.2 \%$ & $44.4 \%$ & $100 \%$ & 3,712 \\
\hline 19th century (Taranovsky's data) & $82.1 \%$ & $96.8 \%$ & $34.6 \%$ & $100 \%$ & 18,445 \\
\hline
\end{tabular}

As we can see, the situation is actually the opposite: the second ictus in Sluchevsky's narrative poems is even more frequently stressed than in the narrative poems of the second half of the nineteenth century in general.

Consequently, Bailey's pioneering study transforms the traditional view of the structure of nineteenth-century Russian iambic tetrameter. ${ }^{3}$ There are several reasons for the discrepancy between Bailey's data and Taranovsky's data. The main one is Taranovsky's subjective choice of poetic texts for examination; he excluded from consideration works whose structure did not correspond to

\footnotetext{
1 In Sluchevsky's narrative verse "the difference between the first ictus and the second ictus is only 3.5\%" (Bailey 2004: 151).

2 This row contains our data (we examined the poems of Nikolai Nekrasov, Apollon Maikov, Yakov Polonsky, and Karolina Pavlova - see Appendix I).

3 Representative data on nineteenth-century lyrical poems are still lacking (in Taranovsky's statistics the post-Pushkin period is represented almost exclusively by astrophic narrative, i. e. lyroepic verse). Our analysis of control samples taken from Polonsky's lyrics confirms the conclusions drawn from the material of lyroepic verse (see Appendix II).
} 
his (erroneous, as it turns out) views on the rhythm and evolution of Russian iambic tetrameter (Liapin 2016).

It is also symptomatic that Sluchevsky's lyroepic verse differs significantly from his lyrics (Bailey 1975). Let us compare two twelve-line samples, one a lyrical poem by Sluchevsky (left) and the other a fragment from his narrative poem (right):

Не́т, не от все́х предубежде́ний

Я и поны́не отрешён!

Но всё свобо́дней се́рдца ге́ний

От все́х обвя́зок и пелён.

Бледне́ет вся́кая усло́вность, Мельча́ет смы́сл в любо́й борьбе́...

В душе́ вели́кая гото́вность

Свобо́дной бы́ть само́й в себе́;

И в э́той пра́вде - не слаща́вость,

Не пра́здный зву́к краси́вых сло́в,

А во́льной мы́сли велича́вость

Под ля́згом все́х земнь́х око́в...
В уса́дьбе шу́м и сумато́ха;

Тако́го в не́й переполо́ха

Не по́мнят. От нача́ла дня́

Повсю́ду сту́к и беготня́;

Уж ско́лько ра́з зашли́ попо́вна

И попадья́ - взгляну́ть на до́м:

Как бу́дет сде́лан в нём приём?

Одна́ Мари́я хладнокро́вна,

По ви́ду, пра́вда, но своё

Испо́лнила. Она́ реши́ла,

Чтобы Царя́ в дому́ ея́

Было́е вре́мя окружи́ло!

In the astrophic narrative poem, sentence length varies considerably more freely than in the lyrical poem, which is divided into quatrains. Therefore, the boundaries of a syntagma in the narrative poem diverge from the boundaries of a verse line more often than in the lyrical poem. The non-coincidence between the syntactic segmentation of the text and the verse segmentation leads to an increase in the number of enjambments (run-on lines), which is accompanied by an increase in the number of syntactic pauses within a verse line (often marked with punctuation marks). Elsewhere (Liapin 2016), I demonstrated that, in run-on lines, rhythmical Form III of iambic tetrameter ( $\sim \sim \sim \sim \sim \sim \sim \sim(\checkmark)$, with stress omitted at the second ictus) is more frequent, as is the case with the example above. This effect is explained by the fact that the beginning of the line more often than not coincides with the beginning of a sentence or clause, and the Russian syntagma is more frequently stressed in the middle. Wherever the use of enjambment increases, the second ictus is less frequently stressed because the beginning of the syntagma moves to the middle of the line. As a result, the frequency of stresses on the second foot decreases. In such cases, we can effectively single out the speech factor and assess its influence on the structure of verse. 
2.

Let us now compare two four-foot-iambic narrative poems written by Nikolai Nekrasov in the 1850s, "Unfortunates" ("Neschastnye") and "V. G. Belinsky" (see Fig. 1). Svetlana Matyash showed that these poems differ significantly in the use of enjambments: $8.5 \%$ in "Unfortunates" and 12.9\% in "V. G. Belinsky" (Matyash 2017: 37, 57; data revised in comparison with Matyash 2001: 174, 180 ). The stress profiles of these two poems are quite different. According to the nomenclature proposed by Taranovsky (2010:413), the poem "Unfortunates" belongs to the "A type" profile (the second ictus is more frequently stressed than the first ictus), whereas the poem "V. G. Belinsky" belongs to the "B type" profile (the first ictus is more frequently stressed than the second ictus):

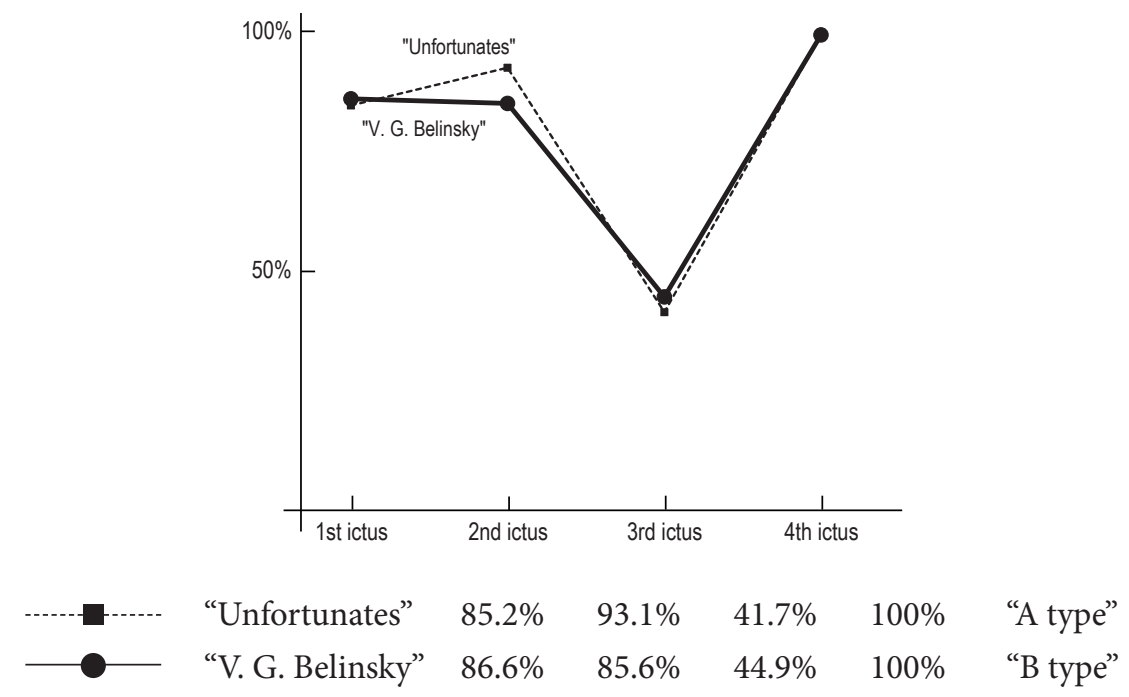

Figure 1. The stress profiles of "Unfortunates" and "V. G. Belinsky" by Nekrasov

The data on "V. G. Belinsky" (these data are missing from Taranovsky's statistics; for another example - Karolina Pavlova’s "Quadrille" - see Appendix I) refute the idea that the "B Type" profile was impossible in the mid-nineteenth century, as Taranovsky claimed: "[...] in epic poetry after 1820 [...] a new twopeak inertia of Russian iambic tetrameter ['A type'] developed [...]. It is because of this that none of the later poets of the nineteenth or twentieth century returned to the one-peak rhythmic inertia of the eighteenth century ['B type']" (Taranovsky 1953: 338; 2010: 328-329). 
If we include only lines without internal punctuation marks in the statistics, the stress profiles of both poems will be similar, and both will belong to "A type" (Fig. 2).

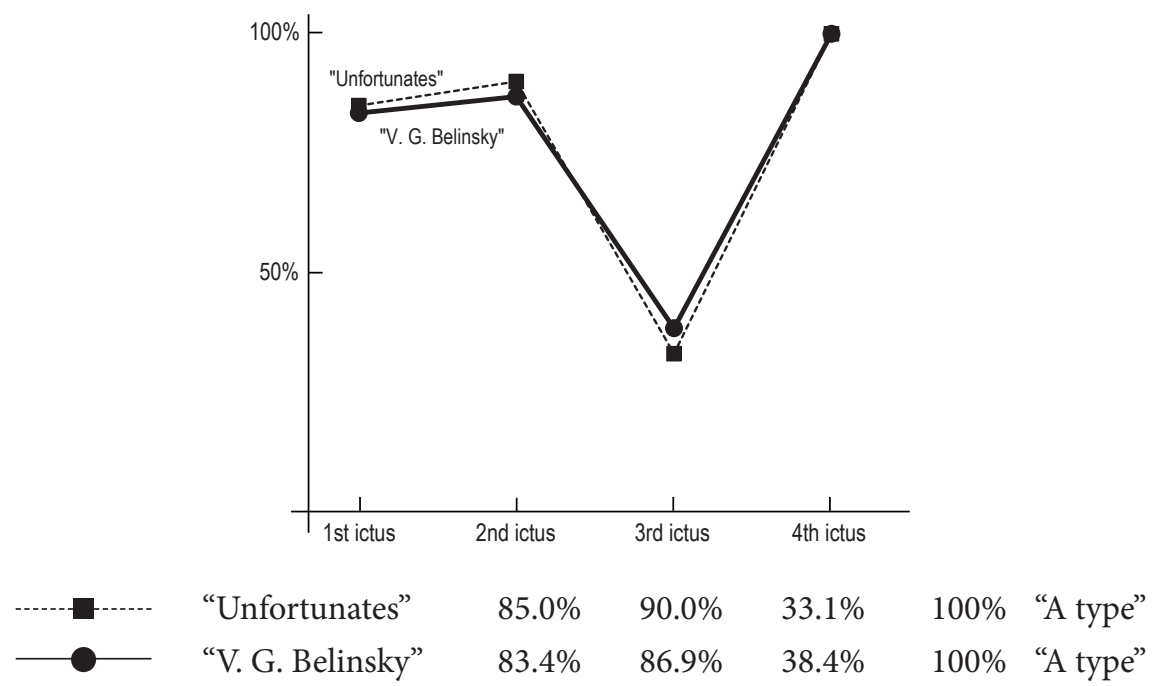

Figure 2. The stress profiles of "Unfortunates" and "V. G. Belinsky": lines without inner punctuation

The same effect is observed in speech-based modeling of Russian iambic tetrameter. We took a portion of Ivan Goncharov's prose, "Oblomov's Dream," as our material. If we include in the statistics all the segments of this text that fit into iambic tetrameter, then the model stress profile will look like Fig. 3.

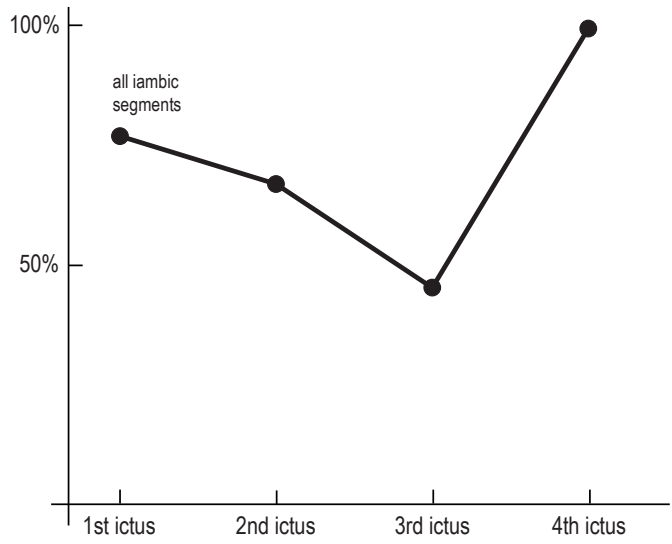

Figure 3. The stress profile of four-foot-iambic segments in Oblomov's Dream 
But, if we select lines without internal punctuation and compare the two resulting profiles, we get the same correlation as in real verse: all the model lines together make up a "B type" profile, but the model lines without internal punctuation belong to "A type" (Fig. 4).

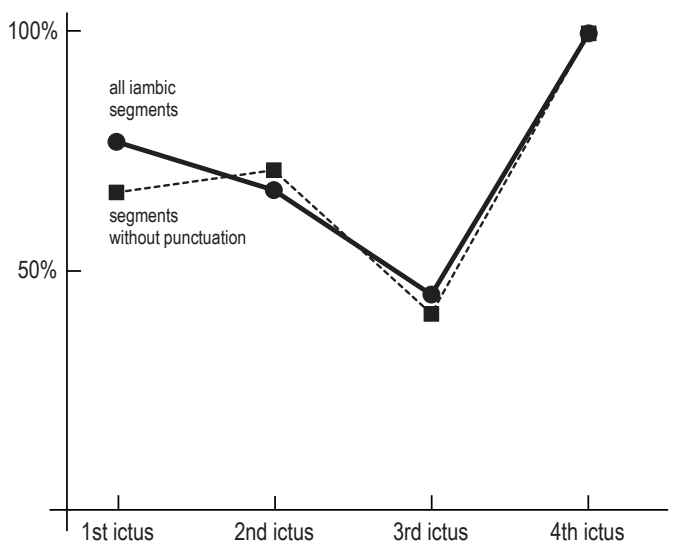

\begin{tabular}{rrrrrrl}
$66.7 \%$ & $71.4 \%$ & $41.3 \%$ & $100 \%$ & $\begin{array}{l}\text { iambic segments without } \\
\text { internal punctuation }\end{array}$ & $\begin{array}{l}\text { "A type" } \\
\text { "B type" }\end{array}$ \\
\hline & $77.3 \%$ & $67.2 \%$ & $45.3 \%$ & $100 \%$ & all iambic segments &
\end{tabular}

Figure 4. The stress profile of four-foot-iambic segments in "Oblomov's Dream": all model lines vs. model lines without internal punctuation

Here are the first ten model lines (lines with punctuation marks are in the right column, and lines without punctuation marks are in the left column):

благослове́нный уголо́к

Оно́ наво́дит то́лько гру́сть

та̀к незаме́тно исчеза́ет

и тяжело́ ему́ смотре́ть

и де́ржат в стра́хе и тоске́
Где́ мы̀? В како́й благослове́нный

та̀м мо́ря, не́т высо́ких го́p

оди́н и то́т же сто́н, одни́

как осужде́нные, уны́ло

та̀м, ка́жется, напро́тив, бли́же

Therefore, the stress profile of a verse line does not enable us to reveal all the relevant features of the accentual structure of the poetic text, nor to distinguish and identify the factors that influenced the formation of this structure. 
3.

To understand, even at first approximation, how Russian iambic tetrameter was formed and how it evolves, it is necessary to take into account all its rhythmical forms in their changing proportions. We will start with several illustrative examples, which nevertheless provide an outline of the structure and evolution of Russian iambic tetrameter.

Figure 5 presents rhythmic diagrams for both of Nekrasov's narrative poems, which we have already examined. The distribution of seven rhythmical forms $\mathrm{s}^{4}$ is similar in both poems, and the aforementioned difference in the frequencies of Form III (the result of enjambments) does not affect the rest of the rhythmical curve.

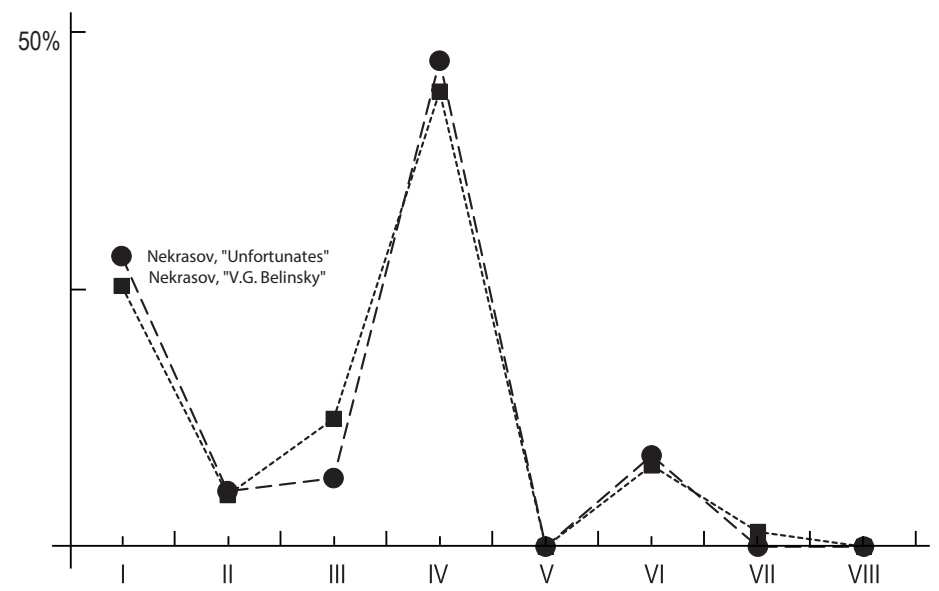

Figure 5. Distribution of rhythmical forms in "Unfortunates" and "V. G. Belinsky"

The distribution of rhythmical forms of iambic tetrameter in Aleksandr Pushkin's narrative poems is not much different from that of Nekrasov's (see Fig. 6).

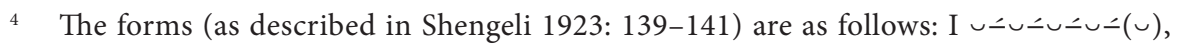

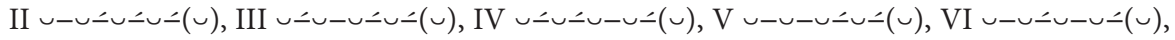

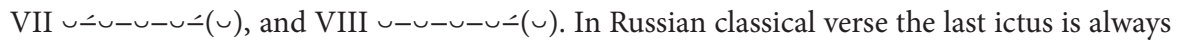
stressed. Forms V and especially VIII are exceptionally rare.
} 


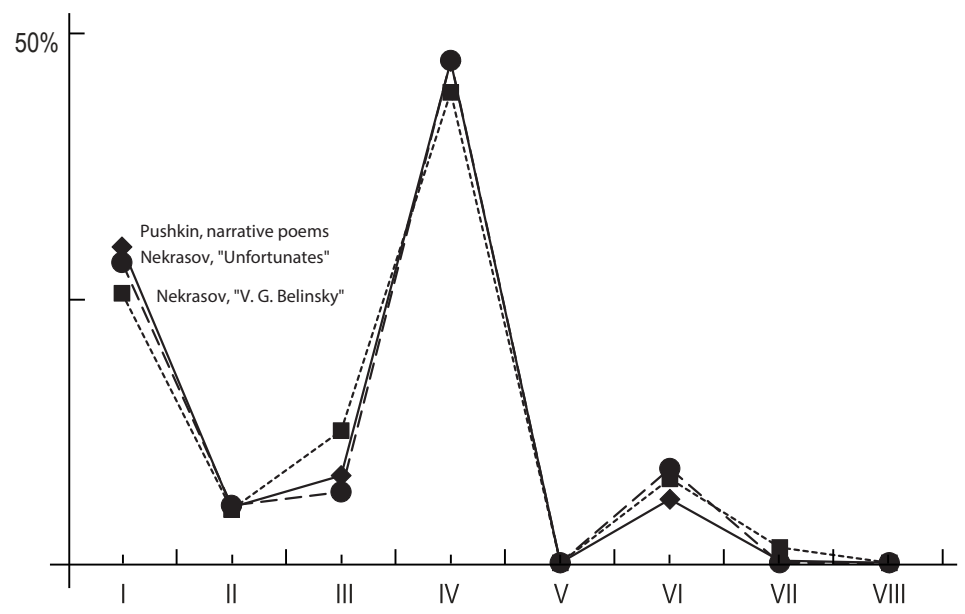

Figure 6. Distribution of rhythmical forms in Pushkin's narrative poems as compared to Nekrasov's "Unfortunates" and "V. G. Belinsky"

The distribution of rhythmical forms of Russian iambic tetrameter changes dramatically only in the twentieth century. To illustrate this, we examined Ivan Elagin's poem "Naplyv" ("Dissolve", 1979-82). The poem's extremely emancipated verse (see Liapin 2016) knows no restrictions - other than those of natural common speech - in the use of rhythmical forms VI and VII (in which two schematic stresses are skipped). See Fig. 7. 


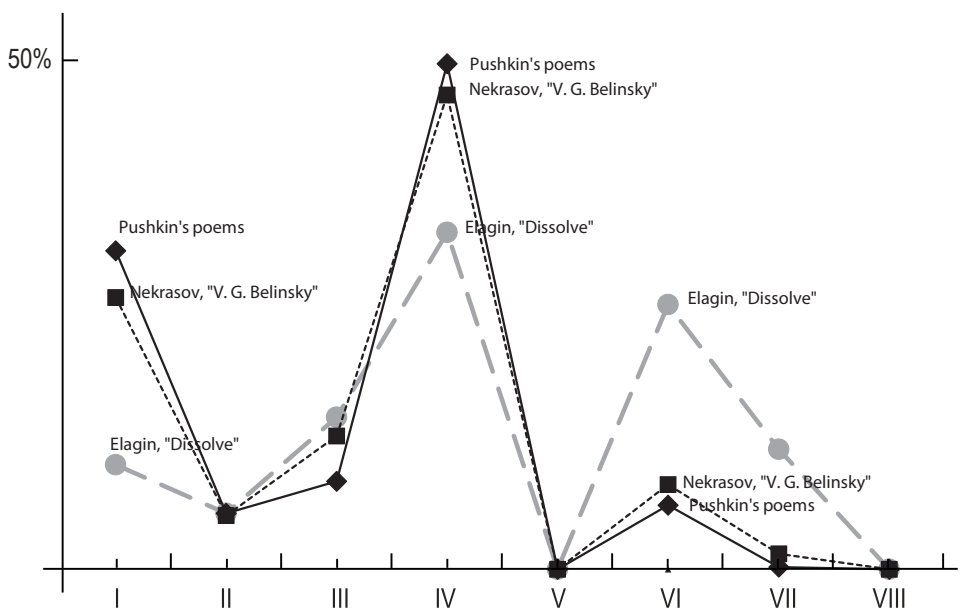

$\begin{array}{cccccccl}\text { I } & \text { II } & \text { III } & \text { IV } & \text { V } & \text { VI } & \text { VII } & \text { Rhythmical forms } \\ 30.8 \% & 5.4 \% & 8.5 \% & 48.9 \% & - & 6.2 \% & 0.2 \% & \text { Pushkin's narrative poems } \\ 29.3 \% & 5.6 \% & 6.9 \% & 49.0 \% & - & 9.2 \% & - & \text { Nekrasov's “Unfortunates" } \\ 26.3 \% & 5.2 \% & 12.9 \% & 45.9 \% & - & 8.2 \% & 1.5 \% & \text { Nekrasov's “V. G. Belinsky" } \\ 10.1 \% & 5.4 \% & 14.7 \% & 32.6 \% & - & 25.6 \% & 11.6 \% & \text { Elagin's "Dissolve” }\end{array}$

Figure 7. Distribution of rhythmical forms in Elagin's "Dissolve" as compared to Pushkin's narrative poems and Nekrasov's "V. G. Belinsky"

Here are two revealing poetic fragments, one from Pushkin's "Poltava", the other from Elagin's poem "Dissolve".

Pushkin:

...Tиха́ укра́инская но́чь. IV

Прозра́чно не́бо. Зве́зды бле́щут. I

Свое́й дремо́ты превозмо́чь IV

Не хо́чет во́здух. Чу́ть трепе́щут I I

Сребри́стых то́полей листы́. IV

Луна́ споко́йно с высоты́ $\quad$ IV

Над Бе́лой-Це́рковью сия́ет IV

И пы́шных ге́тманов сады́

И ста́рый за́мок озаря́ет. IV

И ти́хо, ти́хо всё круго́м; I

Но в за́мке ше́пот и смяте́нье. IV 
В одно́й из ба́шен, под окно́м, IV

В глубо́ком, тя́жком размышле́нье, IV

Око́ван, Кочубе́й сиди́т III

И мра́чно на́ небо гляди́т. IV

Зау́тра ка́знь. Но без боя́зни IV

Он мы́слит об ужа́сной ка́зни; III

О жи́зни не жале́ет о́н... III

Elagin:

...Мы выезжа́ли из Чика́го, VI

А мо́жет бы́ть, из Коното́па, IV

Из Ки́ева, из Магада́на. VII

И, как в ата́ку из око́па, VI

Кида́лся ве́тер из овра́га IV

И налета́л на на́с нежда́нно. II

Мы выезжа́ли из Чика́го. VI

Нас бы́ло че́тверо в маши́не. IV

Тот де́нь был днём после́дним го́да. I

Шоссе́ беле́ло, как бума́га, IV

Стоя́ла зи́мняя пого́да, IV

Но сне́га не́ было в поми́не. IV

Но па́мять не даёт мне спу́ску, III

Переставля́ет то́ и э́то II

По со́бственному произво́лу. VII

(Вот по Андре́евскому спу́ску VI

Мчит Ско́рой по́мощи каре́та IV

По направле́нию к Подо́лу.).. VI

Elagin's iambic tetrameter reflects something quite usual for twentieth-century Russian verse, i. e., rhythmic diversity that is evident in the frame of a single poetic text. By contrast, we can clearly see the more uniform rhythm of "Poltava", typical of the nineteenth century".

5 Compare the frequencies of the lines with two omitted schematic stresses:

Pushkin's narrative poems

$6.4 \%$

Nekrasov's "Unfortunates"

$9.2 \%$

Nekrasov's "V. G. Belinsky” $\quad 9.7 \%$

Elagin's "Dissolve” $\quad 37.2 \%$ 
4.

Rhythmic diversity is an autonomous and aesthetically significant feature of verse. It can be described using entropy, a measure that was recently introduced into scholarly parlance by Andrei Dobritsyn (2016). The higher the entropy, the more diverse the verse rhythm. We have calculated the values of this parameter for Russian iambic tetrameter of the eighteenth, nineteenth, and twentieth centuries. The material used was Mikhail Gasparov's data on nine poets of the eighteenth century ${ }^{6}$; our data on nineteenth-century lyroepic (narrative) verse (see Appendix I) with the addition of figures for the lyrical verse of Tiutchev, Fet, and Polonsky"; and data on Elagin's "Dissolve" with the addition of G. S. Smith's data on twentieth-century lyrics (1945-68: Korvin, Piotrovsky, Klenovsky, Morshen, from Smith 2002: 253, 259). Figure 8 illustrates the gradual increase in the diversity of Russian iambic tetrameter, and the stability of the trend suggests this is an evolutionary process.

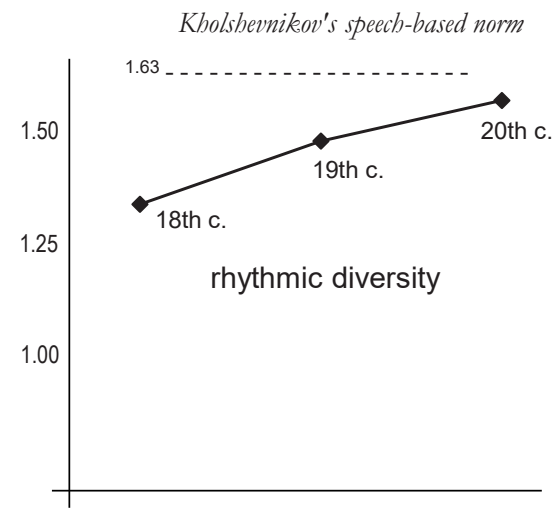

Entropy as a measure of rhythmic diversity

18th c. 19th c. 20th c. Speech-based norm

$\begin{array}{llll}1.34 & 1.48 & 1.57 & 1.63\end{array}$

Figure 8. The growth of rhythmic diversity of Russian verse

"Oblomov's Dream", all model lines $24.3 \%$

"Oblomov's Dream", lines without internal punctuation $\quad 31.7 \%$

6 Lomonosov, Sumarokov, Vasily Maikov, Kheraskov, Vasily Petrov, Derzhavin, Kostrov, Nikolev, Kapnist (Gasparov 1982).

$7 \quad$ Tiutchev 1844-73 (Taranovsky 1953), Fet's Vechernie ogni (Evening Lights, 1842-92) (Shengeli 1923), Polonsky 1871-90 (Liapin 2016). 
It is significant that the level of rhythmic diversity continuously approaches the speech norm first established by Vladislav Kholshevnikov (cf. Liapin 2016). This fact agrees with the observations of Andrei Kolmogorov, who noted "the tendency to maximize the use of all means of language within the limits prescribed by meter and some additional restrictions" (Kolmogorov 2015: 201). We must, however, make an important clarification. The limit to which verse tends is not the purely stochastic norm determined by the so-called "theoretical" (i. e., language-based) model of verse, but the natural speech-based norm, determined by the complex semantic-syntactic relations that arise in the flow of coherent speech. This is clearly seen when comparing the two models based on their proximity to real verse. To measure it, the "relative entropy", also known as the Kullback entropy or the Kullback-Leibler divergence and described in detail by Dobritsyn (2016), is most suitable (see Table 2).

Table 2. The divergence of the distribution of rhythmical forms in verse from the modeled (language-based and speech-based) distribution of the same forms

\begin{tabular}{|l|l|l|l|}
\hline & 18 th c. & 19 th c. & 20 th c. \\
\hline Kholshevnikov's model (speech-based norm) & 0.31 & 0.18 & 0.05 \\
\hline Stochastic model (language-based norm) & 0.31 & 0.24 & 0.10 \\
\hline
\end{tabular}

In the eighteenth century, verse is equally distant from both models. But by the nineteenth and twentieth centuries, its "entropic distance" from the speech norm formed by that time (see Liapin 2016) was much smaller than the divergence between verse and the language-based stochastic model. These data require further elaboration.

\section{Conclusion}

The traditional picture of the evolution of Russian iambic tetrameter, formed under the influence of Kiril Taranovsky's studies, does not stand up to an objective analysis of the poetic texts of the nineteenth and twentieth centuries. The influence of extra-rhythmical factors such as the frequency of enjambments and the stanzaic structure of poetic texts on the formation of verse is comparable to the rhythmic tendencies proper. The identification of these rhythmic tendencies in the evolution of verse requires both the bracketing of external factors (such as speech factors) and a detailed analysis of the accentual structure of each poetic text and each homogeneous group of texts. The 
stress profile of the poetic text does not reflect some essential features of verse rhythm; in particular, it does not reveal the main trend in the evolution of Russian iambic tetrameter - the constant increase in its rhythmic diversity, which is due to the tendency of verse to approximate to the natural speech norm. In this type of verse, the proportions of rhythmical forms are determined not by specific laws, but by the general regularities of the unfolding of coherent speech. ${ }^{8}$

\section{Appendix I}

Russian lyroepic (narrative) iambic tetrameter of the nineteenth century (postPushkin period)

\begin{tabular}{|c|c|c|c|c|c|c|c|c|}
\hline Rhythmical forms & I & II & III & IV & V & VI & VII & $\begin{array}{l}\text { Total } \\
\text { lines }\end{array}$ \\
\hline $\begin{array}{l}\text { Ap. Maikov’s “Two } \\
\text { Worlds”, pt. } 1\end{array}$ & $34.0 \%$ & $9.4 \%$ & $11.1 \%$ & $36.7 \%$ & - & $7.8 \%$ & $1.1 \%$ & 371 \\
\hline $\begin{array}{l}\text { Nekrasov’s } \\
\text { “Tishina” (“Silence”) }\end{array}$ & $\%$ & $8.3 \%$ & $11.5 \%$ & $44.8 \%$ & - & $13.0 \%$ & - & 19 \\
\hline $\begin{array}{l}\text { Nekrasov's "V. G. } \\
\text { Belinsky" }\end{array}$ & $26.8 \%$ & $5.2 \%$ & $12.9 \%$ & $45.4 \%$ & - & $8.2 \%$ & $1.5 \%$ & 194 \\
\hline $\begin{array}{l}\text { Polonsky's "Fresh } \\
\text { Legend", pt. } 1\end{array}$ & $23.3 \%$ & $10.3 \%$ & $11.6 \%$ & $40.9 \%$ & - & $10.6 \%$ & $3.3 \%$ & 604 \\
\hline $\begin{array}{l}\text { Polonsky's "Fresh } \\
\text { Legend", pt. } 6\end{array}$ & $22.7 \%$ & $9.3 \%$ & $13.2 \%$ & $41.1 \%$ & - & $10.4 \%$ & $3.3 \%$ & 6 \\
\hline $\begin{array}{l}\text { K. Pavlova's } \\
\text { "Quadrille" }\end{array}$ & $25.3 \%$ & $9.4 \%$ & $19.8 \%$ & $32.9 \%$ & - & $10.5 \%$ & $2.2 \%$ & 764 \\
\hline $\begin{array}{l}\text { Ap. Maikov’s “Two } \\
\text { Worlds”, pt. } 2\end{array}$ & $36.3 \%$ & $7.8 \%$ & $10.8 \%$ & $37.2 \%$ & - & $6.6 \%$ & $1.4 \%$ & 651 \\
\hline All poems & $27.4 \%$ & $9.0 \%$ & $13.6 \%$ & $38.5 \%$ & - & $9.5 \%$ & $2.2 \%$ & \\
\hline
\end{tabular}

8 Translated by Igor Pilshchikov and Lydia Roberts. The author is grateful to Andrei Dobritsyn, Larisa Liapina, Mihhail Lotman, and Igor Pilshchikov for fruitful discussions of the themes relevant to this article. 


\section{Appendix II}

Stress profile of Russian iambic tetrameter after 1840

\begin{tabular}{lcccccc} 
& \multicolumn{5}{c}{ Ictuses } \\
& & 1 & 2 & 3 & 4 & $\begin{array}{r}\text { Total } \\
\text { lines }\end{array}$ \\
\multicolumn{2}{l}{} & & & & & 3450 \\
19th-century astrophic lyroepic verse & $81.6 \%$ & $84.3 \%$ & $49.9 \%$ & $100 \%$ & 340 \\
Polonsky's lyrical & astrophic poems & $79.3 \%$ & $86.5 \%$ & $47.6 \%$ & $100 \%$ & 208 \\
poems, 1840s-1850s & stanzaic poems & $73.4 \%$ & $96.0 \%$ & $42.7 \%$ & $100 \%$ & 124 \\
Sluchevky (James & astrophic poems & $84.7 \%$ & $88.2 \%$ & $44.4 \%$ & $100 \%$ & 3712 \\
Bailey's data) & lyrical poems & $83.4 \%$ & $95.9 \%$ & $43.7 \%$ & $100 \%$ & 3745
\end{tabular}

Tiutchev (1844-73)

Nekrasov's "Unfortunates" (1856)

Mei, "Blind from Birth" (1855)

A. K. Tolstoy, "John Damascene" (1859)

Fet, "Sabina” (1857?)

\begin{tabular}{ccccc}
\multicolumn{5}{c}{ Ictuses } \\
1 & 2 & 3 & 4 & $\begin{array}{c}\text { Total } \\
\text { lines }\end{array}$ \\
$77.9 \%$ & $90.8 \%$ & $41.2 \%$ & $100 \%$ & 1594 \\
$85.2 \%$ & $93.1 \%$ & $41.7 \%$ & $100 \%$ & 894 \\
$79.8 \%$ & $97.7 \%$ & $30.9 \%$ & $100 \%$ & 223 \\
$87.0 \%$ & $98.4 \%$ & $37.3 \%$ & $100 \%$ & 546 \\
$84.8 \%$ & $95.1 \%$ & $35.3 \%$ & $100 \%$ & 244
\end{tabular}

The data provided in the second table are taken from Taranovsky (1953), whose statistics Bailey (1975) also used. ${ }^{10}$

9 Bailey's data on the lyrical poems of Sluchevsky are, most likely, based mainly on stanzaic poems (prevailing in Sluchevsky).

10 The preliminary results of this study were presented at the Quantitative Approaches to Versification conference (Prague, June 24-26, 2019), see Liapin 2019. Unfortunately, in this publication, where Taranovsky's data are discussed, a fragment (marked here in italics) was omitted in the following phrase:

"[...] [new data for the second half of the 19th century], and especially concerning longer narrative poems of the second half of the 19th century in addition to earlier narrative poems and shorter lyrics taken by Taranovsky, may be important for the whole picture of Russian iambus development".

As a result, the meaning of the sentence changed significantly. 


\section{References}

Bailey, James 1975. The Metrical and Rhythmical Typology of K. K. Slučevskiy’s Poetry. In: International Journal of Slavic Linguistics and Poetics 18, 93-117.

Bailey, James 2004. Izbrannye stat'i po russkomu literaturnomu stikhu. Moskva: Jazyki slavjanskoj kul'tury.

Červenka, Miroslav 1973. Ritmicheskij impul's cheshskogo stikha. In: Jakobson, Roman; Schooneveld, Cornelis H. van; Worth, Dean S. (eds.), Slavic Poetics: Essays in Honor of Kiril Taranovsky. The Hague, Paris: Mouton, 79-90.

Dobritsyn, Andrei 2016. Rhythmic entropy as a measure of rhythmic diversity (The example of the Russian iambic tetrameter). In: Studia Metrica et Poetica 3(1), 33-52. https://doi.org/10.12697/smp.2016.3.1.02

Gasparov, Mikhail Leonovich 1982. Materialy po ritmike russkogo 4-stopnogo jamba XVIII veka. In: Russian Literature 12(2), 195-216.

Gasparov, Mikhail Leonovich 2003. Perepiska K. F. Taranovskogo s V. E. Kholshevnikovym: Posleslovie. In: Acta linguistica petropolitana 1(3), 374-378.

Kholshevnikov, Vladislav Evgen'evich 1973. Sluchajnye chetyrekhstopnye jamby v russkoj proze. In: Jakobson, Roman; Schooneveld, Cornelis H. van; Worth, Dean S. (eds.), Slavic Poetics: Essays in honor of Kiril Taranovsky. The Hague, Paris: Mouton, 549-557.

Kolmogorov, Andrei Nikolaevich 2015. Trudy po stikhovedeniju. Ed. by Prokhorov, Aleksandr Vladimirovich. Moskva: MTsNMO.

Liapin, Sergei Evgen'evich 2016. The Russian iambic tetrameter: The problem of description (Prolegomena to a new paradigm). In: Studia Metrica et Poetica 3(2), 99-127. https://doi.org/10.12697/smp.2016.3.2.04

Liapin, Sergei Evgen'evich 2019. Rhythmical Structure of Russian Iambic Tetrameter and Its Evolution. In: Plecháč, Petr; Scherr, Barry P.; Skulacheva, Tatyana; Bermúdez-Sabel, Helena; Kolár, Robert (eds.), Quantitative Approaches to Versification. Prague: The Institute of Czech Literature of the Czech Academy of Sciences, 125-130.

Matyash, Svetlana Alekseevna 2001. K istorii i tipologii stikhotvornogo perenosa. In: Gasparov, Mikhail Leonovich; Prokhorov, Aleksandr Vladimirovich; Skulacheva, Tatyana Vladimirovna (eds.), Slavianskij stikh. Lingvisticheskaja i prikladnaja poetika: Materialy mezhdunarodnoj konferentsii 23-27 ijunja 1998 goda. Moskva: Jazyki slavjanskoj kul'tury, 172-186. 
Matyash, Svetlana Alekseevna 2017. Stikhotvornyj perenos (enjambement) v russkoj poezii: ocherki teorii $i$ istorii. Sankt-Peterburg: Izdatel'stvo RGPU imeni A. I. Gertsena.

Shengeli, Georgy Arkadievich 1923. Traktat o russkom stikhe. Chast’ 1: Organicheskaja metrika. Izdanie 2-e, pererabotannoe. Moskva, Petrograd: Gosudarstvennoe izdatel'stvo.

Smith, Gerald S. 2002. Vzgljad izvne. Stat'i o russkoj poezii i poetike. Moskva: Jazyki slavjanskoj kul'tury.

Taranovsky, Kiril 1953. Ruski dvodelni ritmovi I-II. Beograd: Naučna knjiga.

Taranovsky, Kiril [Kirill Fedorovich] 2010. Russkie dvuslozhnye razmery. Stat'i o stikhe. Moskva: Jazyki slavianskoj kul'tury. 